\title{
PENGARUH KARTU MISTERI DALAM MODEL PEMBELAJARAN TGT TERHADAP HASIL BELAJAR TEMATIK SISWA
}

\author{
Risfi Aulia Zahara \\ PGSD Fakultas Ilmu Pendidikan Universitas PGRI Semarang \\ risfiauliazahara@gmail.com \\ Fenny Roshayanti \\ PGSD Fakultas Ilmu Pendidikan Universitas PGRI Semarang \\ Roshayatif2@gmail.com \\ Wawan Priyanto \\ PGSD Fakultas Ilmu Pendidikan Universitas PGRI Semarang \\ Priyantowan4@gmail.com
}

\begin{abstract}
Abstrak
Penelitian ini dilatarbelakangi oleh rendahnya hasil belajar siswa yang belum mencapai KKM yang ditetapkan oleh sekolah. Guru masih menggunakan model konvensional dan belum menggunakan media. Kurangnya kesesuaian strategi pembelajaran yang digunakan merupakan salah satu faktor yang mempengaruhi rendahnya hasil belajar siswa. Permasalahan yang dikaji dalam penelitian ini adalah Bagaimanakah Pengaruh Media Kartu Misteri dalam Model Pembelajaran TGT Terhadap Hasil Belajar Siswa Kelas IV? Tujuan yang hendak dicapai dalam penelitian ini adalah untuk mengetahui dan menganalisis pengaruh kartu misteri dalam model pembelajaran teams games tournament (TGT) terhadap hasil belajar siswa kelas IV SDN 04 Petarukan Pemalang. Jenis penelitian ini adalah penelitian dengan menggunakan pendekatan kuantitatif dengan desain pre-experimental design dengan model one group pre-test post-test design yang digunakan dalam satu kelompok subjek. Populasi dalam penelitian ini adalah seluruh siswa kelas IV SDN 04 Petarukan Pemalang. Sampel yang diambil adalah semua siswa yang berjumlah 20 siswa SDN 04 Petarukan Pemalang. Semua anggota populasi menggunakan teknik sampling jenuh. Data penelitian diperoleh melalui tes, observasi, wawancara dan dokumentasi. Hasil tersebut diperkuat dengan hasil analisis akhir yang telah dilakukan dengan menggunakan uji-t diperoleh $\mathrm{t}_{\text {hitung }}=8,862$. Dari data distribusi $\mathrm{t}$ dengan $\mathrm{db}=20-1=19$, dengan taraf signifikan $\alpha=5 \%$ diperoleh $\mathrm{t}_{\text {tabel }}=$ 1,729. Karena $t_{\text {hitung }}>t_{\text {tabel }}$ maka $H_{O}$ ditolaj dan $H_{a}$ diterima, sehingga dapat disimpulkan bahwa "Ada Pengaruh Kartu Misteri Dalam Model Pembelajaran TGT Terhadap Hasil Belajar Siswa Kelas IV”. Berdasarkan hasil penelitian ini saran yang disimpulkan adalah media kartu misteri dapat digunakan sebagai media modifikasi guru dalam pembelajaran. Implikasi dari penelitian ini memiliki pengaruh terhadap hasil belajar siswa yang meningkat dan menciptakan suasana kelas menjadi aktif dan menyenangkan.
\end{abstract}

Kata Kunci: Kartu Misteri, Model Pembelajaran TGT, Hasil Belajar

\begin{abstract}
This research is motivated by the low learning outcomes of students who have not yet reached the KKM set by the school. The teacher still uses conventional models and has not used the media. The lack of appropriateness of the learning strategy used is one of the factors that affects the low student learning outcomes. The problem examined in this study is How is the Effect of the Mystery Card Media in the TGT Learning Model on Class IV Student Learning Outcomes? The aim of this research is to find out and analyze the influence of mystery cards in the Teams Games Tournament (TGT) learning model on the learning outcomes of Grade IV SDN 04 Petarukan Pemalang. This type of research is a study using a quantitative approach to the design of pre-experimental design with one group pre-test post-test design models used in one subject group. The population in this study were all students of grade IV SDN 04 Petarukan Pemalang. Samples taken were all students, amounting to 20 students at SDN 04 Petarukan Pemalang. All members of the population use saturated sampling techniques. Research data obtained through tests, observations, interviews and documentation. These results are strengthened by the results of the final analysis that has been carried out using the $\mathrm{t}$-test obtained tcount $=8.862$. From the data distribution of $\mathrm{t}$ with $\mathrm{db}=20-1=19$, with a significant level $\alpha=5 \%$, obtained ttable $=1.729$. Because $\mathrm{t}>\mathrm{t}$ table then $\mathrm{HO}$ is rejected and Ha is accepted, so it can be concluded that "There is an Effect of Mystery Cards in the TGT Learning Model Against Class IV Student Learning Outcomes". Based on the results of this study the suggestion concluded is that the mystery card media can be used as a medium for teacher modification in learning. The implications of this study have an influence on student learning outcomes that improve and create a class atmosphere to be active and fun.
\end{abstract}

Keywords: Mystery Card, TGT Learning Model, Learning Outcomes 


\section{Pendahuluan}

Pendidikan memiliki pengaruh yang sangat penting bagi perkembangan generasi di masa yang akan datang itu artinya pendidikan akan selalu ada sampai akhir hayat. Pendidikan di sekolah dasar merupakan jenjang pendidikan formal yang sangat menentukan pembentukan karakter dan pola berfikir siswa karena pendidikan di sekolah dasar merupakan pendidikan yang melandasi pendidikan berikutnya. Menurut Hakim (2013) pendidikan merupakan salah satu hal penting untuk menentukan maju mundurnya suatu bangsa, maka untuk menghasilkan sumber daya manusia sebagai subjek dalam pembangunan yang baik, diperlukan modal dari hasil pendidikan itu sendiri.

Pembelajaran di tingkat sekolah dasar pada saat ini telah menggunakan pembelajaran tematik. Hal tersebut sesuai dengan Permendikbud No 24 Tahun 2016 Bab I Pasal 1 Ayat 3 yang menyatakan, sebagai berikut: "Pelaksanaan pembelajaran pada Sekolah Dasar atau Madrasah Ibtidaiyah dilakukan dengan pendekatan pembelajaran tematik terpadu, kecuali untuk mata pelajaran Matematika dan Pendidikan Jasmani Olahraga dan Kesehatan (PJOK) sebagai mata pelajaran yang berdiri sendiri untuk kelas IV, V dan VI".

Pembelajaran tematik merupakan pembelajaran yang mengaitkan beberapa mata pelajaran menjadi satu tema. Daryanto (2014:3) menyatakan bahwa pembelajaran tematik diartikan sebagai pembelajaran yang menggunakan tema untuk mengaitkan beberapa mata pelajaran sehingga dapat memberikan pengalaman bermakna bagi siswa. Pembelajaran yang berkualitas tidak hanya di lihat dari hasil belajar yang baik akan tetapi di lihat juga dari prosesnya, apabila sebagian besar siswa terlibat langsung, aktif dalam pembelajaran, menunjukan semangat belajar dan percaya diri yang tinggi.

Berdasarkan wawancara dan observasi awal pada tanggal 7 Maret 2019 di SD Negeri 04 Petarukan yang dilakukan peneliti diperoleh fakta bahwa hasil belajar siswa rendah. Ditemukan bahwa siswa kelas IV SD Negeri 04 Petarukan memiliki rata-rata nilai belum memenuhi Kriteria Ketuntasan Minimum (KKM) yaitu 70 dengan nilai rincian jumlah peserta didik 20 siswa, persentase siswa yang memenuhi KKM sebanyak 7 siswa dengan rata-rata 83,2, sedangkan yang belum tuntas KKM sebanyak 13 siswa dengan nilai rata-rata 43,3. Sehingga ratarata nilai dalam kelas IV siswa SD Negeri 04 Petarukan yaitu 57 (belum memenuhi KKM). Hal tersebut berarti hasil belajar kelas IV belum sepenuhnya mendapatkan hasil yang diharapkan.

Fakta ini disebabkan oleh permasalahan pada saat proses pembelajaran yang dilaksanakan di SD N 04 Petarukan, berdasarkan hasil wawancara serta observasi awal yang di laksanakan pada tanggal 7 Maret 2019 di kelas IV terdapat beberapa permasalahan yang terjadi pada saat proses pembelajaran. Pada saat proses pembelajaran guru belum menggunakan media yang menarik perhatian sehingga pembelajaran kurang menarik dan membosankan, dalam proses pembelajaran guru masih menggunakn media pembelajaran berupa buku siswa tanpa menggunakan media pembelajaran yang lain.

Faktor lain dari permasalahan tersebut yaitu pembelajaran masih berpusat pada guru yang menyebabkan siswa kurang memperhatikan guru sepenuhnya, siswa cenderung pasif, pemalu dan kurang percaya diri dalam menyampaikan pendapatnya, siswa berbicara dengan temannya. Masalah tersebut yang menyebabkan hasil belajar yang di peroleh tidak sesuai dengan yang diharapkan. Permasalahan tersebut dapat diatasi dengan penggunaan model pembelajaran yang inovatif dengan media pembelajaran yang menarik. Dengan demikian dapat menarik perhatian sehingga siswa tidak merasa bosan dalam kegiatan belajar mengajar.

Media dan model pembelajaran memiliki peran yang sangat penting dalam proses belajar mengajar. Fathurrohman (2017:29) berpendapat bahwa model pembelajaran adalah kerangka konseptual yang digunakan sebagai pedoman dalam melakukan kegiatan pembelajaran. Model pembelajaran adalah suatu pola atau cara dalam penyajian suatu materi yang di lakukan oleh guru dalam suatu pembelajaran dengan tujuan agar tercapainya tujuan dari proses pembelajaran. Media pembelajaran dapat membantu guru untuk mempermudah menyampaikan materi pelajaran dalam pembelajaran. Media pembelajaran juga dapat merangsang perhatian, keaktifan dan rasa ingin tahu siswa terhadap materi pelajaran. Media pembelajaran merupakan suatu alat yang dapat digunakan sebagai alat bantu mengajar yang dapat menunjang proses belajar mengajar yang dapat meningkatkan interaksi antara guru dengan siswa.

Model pembelajaran yang digunakan dalam penelitian ini yaitu model pembelajaran Teams Games Tournament (TGT). Model teams games tournament adalah salah satu model pembelajaran dengan menyertakan permainan dalam pembelajaran sehingga pembelajaran menjadi menyenangkan. Model pembelajaran TGT dapat menambah rasa percaya diri dalam kemampuan untuk berfikir mandiri untuk menyelesaikan suatu permasalahan, menemukan informasi dari berbagai sumber, mampu mengembangkan sikap kerjasama dalam kelompok dan belajar dengan temannya sehingga sumber informasi tidak hanya dari guru saja melainkan guru hanya fasilitator untuk siswa. Menurut Hikmah (2018) TGT merupakan salah satu tipe pembelajaran yang membagi peserta didik dalam kelompok-kelompok belajar dengan beranggotakan 5 sampai 6 orang yang memiliki kemampuan, jenis kelamin, ras ataupun etnis yang berbeda. Dengan adanya kelompok heterogen inilah peserta didik berdiskusi dalam kelompoknya, belajar dan bersama-sama mengerjakan tugas yang diberikan oleh guru. Sehingga ketika ada anggota kelompok yang tidak mengerti dengan tugas yang diberikan, maka anggota kelompok lainnya dapat membantu menjelaskannya. Menurut Yudianto (2014) Model pembelajaran kooperatif tipe Teams Games Tournament (TGT) salah satu tipe atau model pembelajaran kooperatif yang mudah diterapkan, melibatkan 
aktivitas seluruh siswa tanpa harus ada perbedaan status, melibatkan peran siswa sebagai tutor sebaya dan mengandung unsur permainan dan penguatan. Menurut Tarigan (2012) Keunggulan pembelajaran tipe TGT adalah adanya turnamen akademik dalam proses pembelajaran. Dimana setiap anggota kelompok mewakili kelompoknya untuk melakukan turnamen. Menurut Shoimin (2014:203) pembelajaran kooperatif TGT adalah salah satu tipe atau model pembelajaran kooperatif yang mudah diterapkan, melibatkan aktivitas siswa tanpa harus ada perbedaan status, melibatkan peran siswa sebagai tutor sebaya dan mengandung unsur permainan dan reinforcement. Menurut Huda (2017:197) berpendapat bahwa Teams games tournament (TGT) merupakan salah satu strategi cooperative learning yang dikembangkan oleh Slavin untuk membantu siswa mereview dan menguasai materi pelajaran.

Adapun langkah-langkah dalam model pembelajaran TGT menurut Slavin (2005:170) diantaranya:

a. Presentasi di kelas (Class Presentation)

b. Belajar tim.

Para siswa mengerjakan lembar kegiatan dalam tim mereka untuk menguasai materi.

c. Permainan (Game)

Game dimainkan diatas meja dengan tiga atau empat (sesuai jumlah kelompok) untuk menguji pengetahuan siswa yang telah diperoleh.

d. Pertandingan (Tournament)

Para siswa memainkan game akademik dalam kemampuan yang homogen.

e. Rekognisi tim (penghargaan kelompok)

Skor tim dihitung berdasarkan skor turnamen anggota tim dan tim tersebut akan direkognisi apabila mereka berhasil melampaui kriteria yang telah ditetapkan sebelumnya.

Kelebihan Model Pembelajaran TGT yaitu: 1) Model pembelajaran TGT membuat siswa tidak bosan dalam mengikuti kegiatan pembelajaran karena model pembelajaran TGT memiliki konsep permainan dalam proses pembelajaran, 2) Model pembelajaran TGT melatih siswa dalam memecahkan suatu permasalahan yang di sajikan guru, 3) Model pembelajaran TGT melatih kemampuan berfikir tingkat tinggi yang dimiliki siswa, 4) Meningkatkan semangat siswa dalam mengikuti proses pembelajaran karena model TGT memiliki konsep permainan dalam proses pembelajaran.

Kekurangan model pembelajaran TGT Shoimin (2014:208) mengemukakan kekurangan yang dimiliki dalam model pembelajaran TGT yaitu sebagai berikut: 1) Membutuhkan waktu yang lama, 2) Guru dituntut untuk pandai memilih materi pelajaran yang cocok untuk model ini, 3) Guru harus mempersiapkan model ini dengan baik sebelum diterapkan. Misalnya, membuat soal untuk setiap meja turnamen atau lomba, dan guru juga harus tahu urutan akade mis peserta didik dari yang tertinggi hingga terendah.

Peran model pembelajaran cooperative learning tipe TGT memiliki pengaruh pada proses pembelajaran. Hal ini dapat dilihat dari suatu penelitian tentang penggunaan model TGT dalam proses belajar mengajar. Penelitian yang dilakukan Fauziah, et al (2016) menemukan bahwa ada peningkatan hasil belajar siswa dalam penerapan model TGT siswa kelas IIIB SD Negeri 70 Kutaraja Banda Aceh dapat diterima. Hasil penelitian menunjukan bahwa:rata-rata aktivitas guru 3,62, rata-rata Partisipasi siswa 3,12, dan hasil belajar mencapai KKM 65 sebanyak 77,27\% sehingga dapat disimpulkan bahwa pembelajaran TGT dapat meningkatkan hasil belajar siswa pada pembelajaran sumber daya alam di SD Negeri 70 Banda Aceh. Selain itu, penelitian yang di lakukan oleh Miawan (2018) menunjukan bahwa terjadi peningkatan sebelum dan sesudah mendapat perlakuan di laksanakan pembelajaran menggunakan model TGT pada kelas eksperimen dan kelas kontrol. Hasil data pretest hasil belajar sebelum mendapatkan perlakuan pada kelas eksperimen diperoleh data 66,57 sedangkan rata-rata pada kelas kontrol diperoleh 65,33. Setelah dilaksanakan pembelajaran menggunakan model TGT berbantu media monopoli sains terpadu pada kelas eksperimen dan model konvensional pada kelas kontrol menunjukan perbedaan yang signifikan. Peningkatan hasil belajar pada kelas eksperimen diperoleh data rata-rata 88,07 dan di kelas kontrol rata-rata 70,30, sehingga dapat disimpulkan bahwa pembelajaran TGT dapat meningkatkan hasil belajar siswa pada konsep gaya SDN Kepandean Tegal. Penelitian A'yuningsih, D. Q (2017) menemukan bahwa Penerapan model pembelajaran kooperatif tipe TGT dalam pembelajaran kimia dapat meningkatkan motivasi dan hasil belajar peserta didik kelas X.

Daryanto (2014:3) pembelajaran tematik diartikan sebagai pembelajaran yang menggunakan tema untuk mengaitkan beberapa mata pelajaran sehingga dapat memberikan pengalaman bermakna bagi siswa. Pembelajaran tematik mengajarkan peserta didik untuk belajar dari berbagai sumber belajar dan peserta didik diminta untuk menggali informasi karena dalam pembelajaran tematik guru hanya sebagai fasilitator saja dan bukan sebagai sumber belajar. Hal tersebut sesuai dengan pendapat Trianto (2011:156) pembelajaran tematik menekankan pada keterlibatan siswa dalam proses belajar secara aktif dan menekankan pada penerapan konsep belajar sambil melakukan sesuatu.

Pembelajaran tematik di SD harus disertai dengan pemilihan media yang tepat sesuai dengan kondisi dari masing-masing siswa. Media dengan menggunakan konsep permainan merupakan media yang inovatif untuk anak SD sehingga mereka tidak bosan dalam mengikuti pembelajaran. 
Media pembelajaran adalah alat bantu yang digunakan oleh guru dalam menyampaikan materi pada saat proses pembelajaran. Media pembelajaran mendorong kreativitas siswa dalam memecahkan suatu permasalahan sehingga melatih siswa untuk berpikir tingkat tinggi. Hakikatnya media pembelajaran sebagai wahana untuk menyampaikan pesan atau informasi dari sumber pesan di teruskan pada penerima, dengan kata lain pesan tersebut adalah materi pembelajaran untuk mencapai tujuan pembelajaran atau sejumlah kompetensi yang telah dirumuskan sehingga dalam penyampaian pesan tersebut membutuhkan media pembelajaran (Rusman 2017:215)

Edgar dale mengemukakan landasan teori penggunaan media pembelajaran dalam kerucut pengalaman (Cone Of Experience) sebagaimana tampak dalam gambar sebagai berikut:

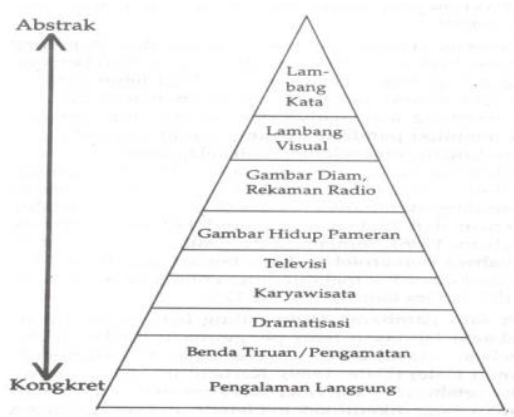

Gambar 1. Kerucut Pengalaman Edgar Dale

(Arsyad 2011:11)

Menurut Huda (2016:135) bahwa gambar tersebut menunjukan rentangan tingkat pengalaman dari yang bersifat langsung sampai yang bersifat pengalaman melalui simbol panca indra yang turut serta dalam penerimaan isi pengajaran atau pesan dan tentunya memberi pengaruh terhadap pemilihan metode dan bahan pengajaran. Arsyad (2011:10) mengemukakan bahwa hasil belajar sesorang diperoleh mulai dari pengalaman langsung (konkret), kenyataan yang ada di lingkungan kehidupan seseorang kemudian melalui benda tiruan, sampai kepada lambang verbal (abstrak).

Berdasarkan pendapat diatas maka dapat disimpulkan bahwa melalui pengalaman langsung siswa dapat memperoleh segala informasi yang di sampaikan guru dan pengalaman tersebut dapat memberikan kesan pada diri siswa karena pengalaman tersebut dapat melibatkan semua indera yaitu indera penglihatan, pendengaran, perasa, penciuman maupun indera peraba. Selanjutnya jika informasi yang diberikan melalui benda tiruan sampai pada simbol/lambang maka indera yang dibatkan semakin sedikit seperti indera penglihatan dan indera pendengaran. Akan tetapi, semakin sedikit indera yang di libatkan maka semakin tinggi tingkatan untuk menafsirkan informasi tersebut.

Media yang digunakan dalam penelitian ini yaitu kartu misteri. Kartu misteri merupakan suatu media inovatif yang cara menggunakannya yaitu dengan permainan dalam suatu kelompok. Kartu misteri merupakan inovasi dari permainan tradisional yaitu kartu domino. Cara bermain kartu misteri juga hampir sama dengan kartu domino tetapi isi dalam kartu tersebut yang berbeda.

Peran media pembelajaran kartu misteri sangat besar pada proses belajar mengajar. Melalui media kartu misteri siswa dapat belajar sambil bermain sehingga pembelajaran menjadi menyenangkan dan tidak membosankan. Selain itu, media kartu misteri dapat meningkatkan semangat belajar, siswa mampu berfikir tingkat tinggi untuk menyelesai permaslahan yang ada dalam kartu misteri dan mampu bekerja sama secara berkelompok. Maka dari itu upaya yang dilakukan untuk meningkatkan hasil belajar siswa yaitu memilih strategi atau cara yang sesuai dalam menyampaikan materi pelajaran dan penggunaan media yang inovatif sehingga diperoleh peningkatan hasil belajar tematik siswa kelas IV.

Adapun langkah-langkah penggunaan kartu misteri dalam model TGT, diantaranya yaitu:

a. Guru menjelaskan materi pada saat pembelajaran dan siswa diminta untuk fokus dalam pembelajaran sehingga siswa mampu menyusun kartu misteri yang sesuai. Guru membentuk kelas menjadi 5 kelompok yang berjumlah 4 anggota kelompok.

b. Guru membagi 20 kartu pada setiap kelompok. Ketua kelompok diminta untuk mengacak kartu dan dibagi rata untuk setiap anggota kelompok.

c. Anggota kelompok meletakan kartu awal/babon di tengah meja sehingga dapat dijangkau oleh setiap anggota kelompok, anggota kelompok mencari jawaban atau pertanyaan yang sesuai dengan isi kartu babon.

d. Anggota kelompok diminta untuk mengidentifikasi kartu jawaban yang sesuai dengan pertanyaan dari kartu sebelumnya. Siswa menyusun kartu misteri sehingga terhubung dari kartu satu ke kartu lainnya. Susunan kartu misteri membentuk menjadi 4 bagian sesuai dengan kartu awal/babon. 
e. Siswa yang kartunya paling cepat habis akan mendapatkan nilai yang lebih dari guru. Kelompok tercepat dalam menghabiskan kartu adalah kelompok pemenang dan guru akan memberikan reward.

Penelitian ini menggunakan pendekatan kuantitatif mengenai pengaruh kartu misteri dalam model pembelajaran TGT terhadap hasil belajar pernah di lakukan oleh beberapa peneliti lain, diantaranya penelitian yang dilakukan oleh:

Fauziah, et al. (2016) berdasarkan hasil penelitian yang dilakukan bahwa terjadi peningkatan sebelum dan sesudah di laksanakan pembelajaran menggunakan model TGT. Metode penelitian ini menggunakan metode penelitian tindakan kelas. Hasil penelitian menunjukan bahwa:rata-rata aktivitas guru 3,62, rata-rata Partisipasi siswa 3,12, dan hasil belajar mencapai KKM 65 sebanyak 77,27\% sehingga dapat disimpulkan bahwa pembelajaran TGT dapat meningkatkan hasil belajar siswa pada pembelajaran sumber daya alam di SD Negeri 70 Banda Aceh. Model yang digunakan Fauziah, et al sama dengan model yang digunakan peneliti yaitu model pembelajaran TGT.

Miawan (2018) berdasarkan hasil penelitian bahwa terjadi peningkatan sebelum dan sesudah mendapat perlakuan di laksanakan pembelajaran menggunakan model TGT pada kelas eksperimen dan kelas kontrol. Metode penelitian ini menggunakan metode penelitian kuantitatif. Hasil data pretest hasil belajar sebelum mendapatkan perlakuan pada kelas eksperimen diperoleh data 66,57 sedangkan rata-rata pada kelas kontrol diperoleh 65,33 . Setelah dilaksanakan pembelajaran menggunakan model TGT berbantu media monopoli sains terpadu pada kelas eksperimen dan model konvensional pada kelas kontrol menunjukan perbedaan yang signifikan. Peningkatan hasil belajar pada kelas eksperimen diperoleh data rata-rata 88,07 dan di kelas kontrol rata-rata 70,30, sehingga dapat disimpulkan bahwa pembelajaran TGT dapat meningkatkan hasil belajar siswa pada konsep gaya SDN Kepandean Tegal.

\section{Metode}

Metode dalam penelitian ini menggunakan metode kuantitatif dan jenis metode yang digunakan yaitu metode eksperimen. Penelitian kuantitatif merupakan penelitian yang di dasari dari fenomena objektif dan di kaji dalam bentuk angka, sedangkan jenis metode penelitian eksperimen merupakan metode penelitian yang digunakan untuk mencari pengaruh treatment (perlakuan) tertentu (Sugiyono 2017:11). Desain penelitian ini menggunakan pre-experimental design dengan model one group pre-test post-test design yang digunakan dalam satu kelompok subjek.

Adapun populasi pada penelitian ini adalah seluruh siswa kelas IV SD N 04 Petarukan. Sampel pada penelitian ini adalah seluruh siswa kelas IV SD N 04 Petarukan yang berjumlah 20 siswa dengan rincian lakilaki berjumlah 7 siswa dan perempuan berjumlah 13 siswa.

Teknik sampling dalam penelitian ini menggunakan non probability sampling dengan jenis sampling jenuh. Maka sampel yang digunakan dalam penelitian ini adalah siswa kelas IV yang berjumlah 20 siswa. Sugiyono (2017:118) menyatakan bahwa teknik sampling adalah merupakan teknik pengambilan sampel. Teknik pengumpulan data yang digunakan dalam penelitian ini yaitu menggunakan wawancara, tes, dan dokumentasi.

Penelitian ini menggunakan tes untuk mengukur hasil belajar kognitif siswa yang di tuangkan dalam pembelajaran tematik tema 2 "Selalu Berhemat Energi" subtema 1 "Sumber Energi" SDN 04 Petarukan. Bentuk tes yang digunakan yaitu tes pilihan ganda dengan jumlah 40 soal. Masing-masing soal memiliki skor 1 jika jawaban benar dan 0 jika jawaban salah. Soal terlebih dahulu di ujicobakan untuk mendapatkan pertanyaanpertanyaan yang valid, reliabel, daya pembeda, dan taraf kesukaran dari tiap-tiap butir tes. Tes pada penelitian ini dengan memberikan soal di akhir pembelajaran. Wawancara dalam penelitian ini dilakukan untuk memperoleh informasi permasalahan yang terjadi di SDN 04 Petarukan. Wawancara dilakukan dengan guru kelas IV SDN 04 Petarukan. Teknik dokumentasi diperlukan peneliti untuk mengambil dokumen atau data yang mendukung penelitian, seperti daftar nama siswa, jumlah siswa dan daftar nilai siswa kelas IV SDN 04 Petarukan serta foto saat pembelajaran berlangsung. Observasi dilaksanakan pada saat kegiatan pembelajaran berlangsung yang bertujuan untuk mengamati proses pembelajaran siswa kelas IV SDN 04 Petarukan. Observasi dilaksanakan sebelum penelitian.

\section{Hasil dan Pembahasan}

Analisis data awal dapat dilihat dari hasil nilai pretest sebelum diberi perlakuan dan analisis data akhir dapat dilihat dari hasil nilai posttest sesudah diberi perlakuan dengan menggunakan media kartu misteri dalam model pembelajaran TGT.

Sebelum dilaksanakan pembelajaran pada kelas IV, siswa terlebih dahulu diberikan soal pretest untuk mengetahui kemampuan awal sebelum diberi perlakuan menggunakan media kartu misteri dalam model pembelajaran TGT. Hal tersebut dilaksanakan untuk mengetahui data berdistribusi normal atau tidak. Kelas IV 
memiliki siswa berjumlah $\mathrm{N}=20$ diperoleh $\mathrm{L}_{\mathrm{o}}$ dari nilai pretest sebesar 0,1528 . Nilai kritis $\mathrm{L}$ untuk uji Liliefors dengan taraf 0,05 diperoleh nilai $\mathrm{L}$ sebesar 0,190. Jadi $L_{o}<L$, sehingga $\mathrm{H}_{\mathrm{o}}$ diterima. Maka dapat disimpulkan bahwa data berdistribusi normal.

Pada tahap akhir, uji normalitas dilaksanakan kembali dengan menggunakan soal posttest. Dilihat dari tabel perhitungan bahwa nilai posttest yang diperoleh kelas IV semuanya berasal dari data berdistribusi normal. Kelas IV memiliki siswa berjumlah $\mathrm{N}=20$ diperoleh $\mathrm{L}_{\mathrm{o}}$ dari nilai posttest sebesar 0,1137 . Nilai kritis $\mathrm{L}$ sebesar 0,190. Jadi $L o<L$, sehingga $\mathrm{H}_{\mathrm{o}}=$ diterima. Maka dapat disimpulkan bahwa data berdistribusi normal.

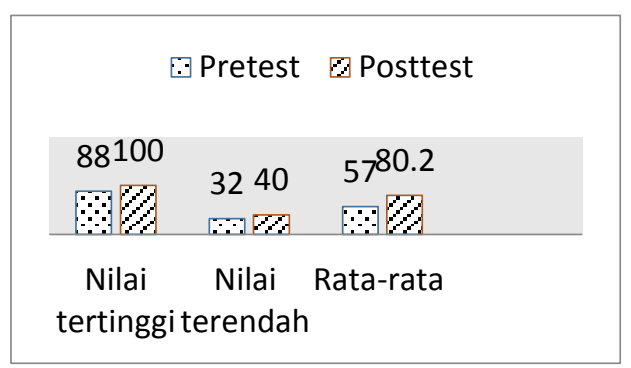

Gambar 2. Nilai Tertinggi, Nilai Terendah dan Rata-Rata pretest-posttest

Gambar 2 menunjukan bahwa ada perbedaan pada nilai pretest dan posttest. Setelah diberi perlakuan dengan menggunakan media kartu misteri dalam model pembelajaran teams games tournament mendapatkan nilai tertinggi yaitu 100 dan nilai terendah yaitu 40 maka memperoleh rata-rata sebesar 80,2. Sedangkan, sebelum diberi perlakuan mendapatkan nilai tertinggi yaitu 88 dan nilai terendah yaitu 32 maka memperoleh rata-rata sebesar 57,0. Dilihat dari rata-rata tersebut terjadi peningkatan yang signifikan pada nilai pretest dan posttest. Hal tersebut menunjukan dalam pelaksanaan posttest dengan perlakuan menggunakan media kartu misteri dalam model pembelajaran TGT dapat diketahui bahwa banyak siswa yang tuntas sebanyak 16 siswa dan 4 siswa yang tidak tuntas. Sedangkan pada saat pelaksanaan pretest sebanyak 7 siswa yang tuntas dan 13 siswa tidak tuntas KKM. Peningkatan hasil nilai pretest dan posttest

Pada tahap selanjutnya, peneliti melakukan uji gain untuk mengetahui peningkatan rata-rata nilai pretest dan rata-rata nilai posttest. Berdasarkan hasil perhitungan, diperoleh peningkatan sebesar 0,54 dengan kategori sedang. Maka, dapat dikatakan bahwa terdapat peningkatan pada rata-rata nilai pretest dan posttest.

Berdasarkan perhitungan uji normalitas awal dan akhir dapat dilihat bahwa $\mathrm{L}_{\text {hitung }}<\mathrm{L}_{\text {tabel }}$, maka dapat disimpulkan kelas tersebut berdistribusi normal. Dari data normalitas awal (pretest) dan normalitas akhir (posttest) menunjukan bahwa populasi berdistribusi normal.

Penelitian yang dilakukan di SDN 04 Petarukan Pemalang bertujuan untuk mengetahui perbedaan hasil belajar siswa antara pembelajaran melalui penggunaan media kartu misteri dalam model TGT dengan pembelajaran konvensional di SDN 04 Petarukan Pemalang. Selain dilihat dari peningkatan nilai pretest dan posttest juga dilakukan uji ketuntasan hasil belajar. Uji ketuntasan belajar dilakukan untuk mengukur kemampuan siswa dalam mencapai tujuan pembelajaran. Uji ketuntasan klasikal dikatakan berhasil apabila sekurang-kurangnya $70 \%$ siswa berhasil mencapai penguasaan yang telah ditetapkan yaitu nilai mencapai KKM. Hasil dari perhitungan uji ketuntasan klasikal diperoleh jumlah siswa yang menguasai pembelajaran diatas nilai KKM mencapai 45\%, maka media kartu misteri dalam model TGT memiliki pengaruh pada hasil belajar siswa. Selanjutnya dilakukan uji t.

Hasil pengujian pada uji t, hasil belajar diperoleh nilai $t_{\text {hitung }}$ sebesar 8,862 dengan $t_{\text {tabel }}$ sebesar 1.729. Jadi nilai $t_{\text {hitung }}>t_{\text {tabel }}$ sehingga $H_{o}$ ditolak dan $H_{a}$ diterima. Artinya ada perbedaan hasil belajar siswa yang signifikan antara pembelajaran melalui penggunaan media kartu misteri dalam model TGT dengan pembelajaran konvensional di SDN 04 Petarukan. Hal ini dapat dibuktikan dengan nilai rata-rata posttest yang lebih besar dibanding nilai rata-rata pretest yaitu 80,2 dan nilai rata-rata pretest yaitu 57.

Hasil penelitian dengan menggunakan media Kartu Misteri dalam model pembelajaran Teams Games Tournament menunjukan bahwa rata-rata pretest yaitu 57, sedangkan rata-rata posttest yaitu 80,2. Hal ini dapat menunjukan secara jelas bahwa pembelajaran menggunakan media kartu misteri dalam model pembelajaran TGT dapat berpengaruh dalam meningkatkan hasil belajar tematik tema 2 "Selalu Berhemat Energi" subtema 1 "Sumber Energi" siswa kelas IV. Sehingga hasil penelitian ini adalah signifikan.

Hasil penelitian ini juga didukung oleh penelitian yang dilakukan oleh Miawan (2018) yang berjudul "Pengaruh Model TGT Berbantu Media Monopoli Sains Terpadu Terhadap Minat dan Hasil Belajar Siswa Kelas IV Pada Konsep Gaya SDN Kepandean Tegal". Berdasarkan hasil penelitian pada data pretest hasil belajar sebelum mendapatkan perlakuan pada kelas eksperimen diperoleh data 66,57 sedangkan rata-rata pada kelas kontrol diperoleh 65,33. Setelah dilaksanakan pembelajaran menggunakan model TGT berbantu media monopoli sains terpadu pada kelas eksperimen dan model konvensional pada kelas kontrol menunjukan 
perbedaan yang signifikan. Peningkatan hasil belajar pada kelas eksperimen diperoleh data rata-rata 88,07 dan di kelas kontrol rata-rata 70,30. Dari hasil tersebut, menunjukan bahwa terdapat peningkatan hasil belajar yang signifikan antara nilai hasil belajar siswa sebelum diberi perlakuan menggunakan model TGT berbantu media monopoli sains terpadu dengan hasil belajar sesudah diberi perlakuan menggunakan model TGT berbantu media monopoli sains terpadu.

\section{Simpulan}

Berdasarkan rumusan masalah, pengajuan hipotesis, analisis data penelitian dan pembahasan, maka dapat disimpulkan bahwa penggunaan media kartu misteri dalam model pembelajaran TGT berpengaruh terhadap hasil belajar tematik tema 2 selalu berhemat energi siswa kelas IV SDN 04 Petarukan. Dibuktikan dari hipostesis, ada perbedaan hasil belajar siswa yang signifikan antara pembelajaran melalui penggunaan media kartu misteri dalam model TGT dengan pembelajaran konvensional yang menjadi model pembelajaran di SDN 04 Petarukan.

Hasil posttest pada kelas IV SDN 04 Petarukan sesudah diberi perlakuan menggunakan media kartu misteri dalam model pembelajaran TGT lebih baik dari hasil pretest sebelum diberi perlakuan menggunakan media kartu misteri dalam model pembelajaran TGT. Rata-rata hasil posttest sesudah diberi perlakuan yaitu sebesar 80,2, sedangkan rata-rata hasil pretest sebelum diberi perlakuan yaitu sebesar 57. Dibuktikan juga dengan hasil perhitungan uji $t$ diperoleh nilai $t_{\text {hitung }}$ sebesar 8,862 dengan $t_{\text {tabel }}$ sebesar 1.729. Jadi nilai $t_{\text {hitung }}>t_{\text {tabel }}$ sehingga $\mathrm{H}_{\mathrm{o}}$ ditolak dan $\mathrm{H}_{\mathrm{a}}$ diterima. Maka, dapat disimpulkan bahwa penggunaan media kartu Misteri dalam model pembelajaran TGT berpengaruh terhadap hasil belajar tematik siswa kelas IV SD N 04 Petarukan Pemalang.

Berdasarkan hasil penelitian, maka peneliti mengajukan saran sebagai berikut: 1) Bagi guru, media kartu misteri dalam model pembelajaran TGT dapat diterapkan dalam pembelajaran selanjutnya. 2) Bagi siswa, dalam pembelajaran secara berkelompok siswa diharapkan mampu berdiskusi dan menghargai pendapat antara satu dengan yang lain. 3) Bagi peneliti, dalam penggunaan kartu misteri dalam model pembelajaran TGT diharapkan peneliti lain mampu meneruskan penelitian ke cakupan belajar yang lebih luas, tidak hanya terfokus pada aspek kognitif saja.

\section{Daftar Pustaka}

Arikunto, Suharsimi. 2013. Dasar-Dasar Evaluasi Pendidikan. Jakarta: Bumi Aksara.

Arsyad, A. 2011. Media Pembelajaran. Jakarta: PT Raja Grafindo Persada.

A’yuningsih, D. Q., Suardana, I. N., \& Suwenten, I. M. (2017). Penerapan Model Pembelajaran Kooperatif Tipe TGT (Teams Games Tournament) Untuk Meningkatkan Motivasi Dan Hasil Belajar Peserta Didik. Jurnal Pendidikan Kimia Indonesia, 1(2), 37-47.

Dahar, Ratna W. 2011. Teori-teori Belajar dan Pembelajaran. Bandung: Erlangga.

Daryanto. 2014. Pembelajaran Tematik, Terpadu, Terintegrasi (Kurikulum 2013). Yogyakarta: Gava Media.

Dimyanti dan Mudjiono. 2009. Belajar dan Pembelajaran. Jakarta: PT Rineka Cipta

Ertikanto, chandra. 2016. Teori Belajar Dan Pembelajaran. Yogyakarta: Media Akademi.

Fauziah, R., \& Subhananto, A. (2016). Penerapan Model Pembelajaran TGT (Teams Games Tournament) untuk Meningkatkan Hasil Belajar Siswa pada Materi Sumber Daya Alam di Kelas III SD Negeri 70 Kuta Raja Banda Aceh. Tunas Bangsa Journal, 3(1).

Fathurrohman. 2017. Model-model Pembelajaran Inovatif. Yogyakarta: Ar Ruz Media.

Hakim, O.Z. (2013). Penerapan Model Pembelajaran Bermain Peran Dalam Pembelajaran Matematika IPS untuk Melihat Motivasi dan Hasil Belajar Siswa di SMAN 16 Palembang. Skripsi. UNSRI Palembang: FKIP Biologi.

Hamalik, omar. 2011. Proses Belajar Mengajar. Jakarta: Bumi Aksara.

Msy Hikmah, Yenny Anwar, dan Riyanto. 2018. Penerapan Model Pembelajaran Team Games Tournament (TGT) terhadap Motivasi dan Hasil Belajar Peserta Didik pada Materi Dunia Hewan Kelas X di SMA Unggul Negeri 8 Palembang. Jurnal Pembelajaran Biologi, Volume 5, Nomor 1, Hal. 46-56. Tersedia Pada: https://ejournal.unsri.ac.id/index.php/fpb/article/view/7049.

Huda, M. (2016). Pembelajaran Berbasis Multimedia dan Pembelajaran Konvensional (Studi Komparasi di MTs Al-Muttaqin Plemahan Kediri). Jurnal Penelitian, 10(1), 125-146.

Huda, Miftahul. 2017. Model-Model Pengajaran dan Pembelajaran. Yogyakarta: Pustaka Pelajar.

Kemendikbud. 2016. Peraturan Menteri Pendidikan dan Kebudayaan Republik Indonesia Tahun 2016 Tentang Kompetensi Inti dan Kompetensi Dasar Pelajaran Pada Kurikulum 2013 Pada Pendidikan Dasar dan Pendidikan Menengah. Jakarta: Kemendikbud.

Miawan, S. 2018. Pengaruh Model TGT Berbantu Media Mopoli Sains Terpadu Terhadap Minat dan Hasil Belajar IPA Siswa Kelas IV Pada Konsep Gaya SDN Kepandean 03 Tegal. Skripsi: Universitas PGRI Semarang. 
Purwanto. 2010. Evaluasi Hasil Belajar. Yogyakarta: Pustaka Pelajar.

Rusman. 2017. Belajar dan Pembelajaran Berorientasi Standar Proses Pendidikan. Jakarta: Kencana.

Sanjaya, W. 2013. Penelitian Pendidikan Jenis, Metode dan Prosedur. Jakarta

Prenadamedia Group.

Shoimin, Aris. 2014. 68 Model Pembelajaran Inovatif dalam Kurikulum 2013. Yogyakarta: Ar-Ruzz Media.

Slavin, Robert E. 2010. Cooperative Learning: Teori, Riset dan Praktik. Bandung: Nusa Media

Soegeng, A.Y. 2016. Filsafat Pendidikan. Yogyakarta: Magnum Pustaka Utama

Sugiyono. 2017. Metode Penelitian dan Pendidikan. Bandung: Alfabeta.

Sudjana, Nana. 2009. Penilaian Hasil Proses Belajar Mengajar. Bandung: PT Remaja Rosdakarya

Suprijono, Agus. 2010. Cooperative Learning. Yogyakarta: Pustaka Media.

Sukmadinata, Nana Syaodiah. 2013. Metode Penelitian Pendidikan. Bandung: PT Remaja Rosdakarya.

Susanto, Ahmad. 2015. Teori Belajar Dan Pembelajaran di Sekolah Dasar. Jakarta: Prenadamedia group.

Suyono dan Hariyanto. 2014. Belajar dan Pembelajaran. Bandung: PT Remaja Rosdakarya.

Tarigan, R. (2012). Pengaruh model pembelajaran kooperatif tipe Teams Games Tournament terhadap hasil belajar IPA Fisika di SMP Negeri 1 Percut Sei Tuan. Jurnal Penelitian Inovasi Pembelajaran Fisika. 4 (2), hlm. 50-55.

Trianto. 2011. Model Pembelajaran Terpadu Konsep, Strategi Dan Implementasinya Dalam Kurikulum Tingkat Satuan Pendidikan (KTSP). Jakarta: Bumi Aksara.

Yudianto, Wisnu D., Kamin Sumardi, Ega T. Berman. 2014. Model Pembelajaran Teams Games Tournament untuk Meningkatkan Hasil Belajar Siswa SMK. Journal of Mechanical Engineering Education, Vol.1, No.2, Hal. 323-330. Tersedia Pada: https://ejournal.upi.edu/index.php/jmee/article/view/3820. 